\title{
TEACHING READING COMPREHENSION THROUGH GENRE-BASED APPROACH (GBA) AT JUNIOR HIGH SCHOOL
}

\author{
Gunawan $^{1}$ \\ ${ }^{1}$ Universitas Muhammadiyah Bone, Indonesia \\ Gunawanjps@gmail.com
}

\begin{abstract}
This research is about teaching reading comprehension through a genre-based approach (GBA) at junior high school. The study aimed to increase students' reading comprehension in the eighth grade at SMP Negeri 1 Sibulue through the Genre-Based Approach (GBA). This research used Classroom Action Research (CAR) that consisted of two cycles. The research subject was the eighth grade of SMP Negeri 1 Sibulue in academic year 2021/2022 that consisting of 25 students. The researcher obtained the data by using a reading test and observation sheet. The results of the students' reading tests in cycle I and cycle II had significantly different scores. There was a better increase of gains by students at the end of the action of the second cycle. The results of the study showed that the score in the first cycle to the second cycle increased based on the value of the first cycle of 61.80 and the second cycle showed 75.80. It could be stated that the student's reading comprehension at the eighth grade of SMP Negeri 1 Sibulue was at a fairly good level after the test in the first cycle and increased to a good level after the test in the second cycle.
\end{abstract}

Keywords: Reading Comprehension, Genre-Based (GBA) Approach

\section{INTRODUCTION}

\subsection{Introduction}

English is still a favorite means of communication among people in the world and it is used all over the world, so, English becomes an important tool for international communication. Therefore, being able to use English, we can easily associate with other people all over the world, and by this capability, people can be easily applied for the job, spread news, work out his or her social relationships.

As it is known that language consists of four skills, namely listening, speaking, writing and reading. These skills must be serving to integrate as much as possible. They are closely related and cannot be separated and also support each other. English students have to master this 
skill as well as possible. In addition, the English language has some elements; grammar, pronunciation, spelling, and vocabulary. Someone will find difficulties in learning English without the elements.

One part of learning a language is knowing about reading skills. Reading functions as the window of knowledge can get much information that students need, (Satriani, 2018). It is used to get information. According to (Floris \& Divina, 2015), reading abilities can increase English abilities and knowledge of the EFL Students.

Reading is an important aspect of life. Many benefits can be obtained from reading, such as improving brain performance, increasing knowledge, and sharpening memory. Experts also agree that reading is important and has a very good impact on humans.

According to (Suyana, 2019), reading is an activity that exerts several actions including physical or cognitive actions. Besides,(Sari et al., 2020) is also stated that Reading comprehension is an activity by reconstructing the reader's knowledge which directs the reader to critically interpret and analyze every part of the text so as to get an understanding of the actual reading content.

Reading habits can increase the students' achievement. as stated by (Calet et al., 2019) Reading comprehension is one of the most important transversal skills for the achievement of success in both school and society.

Students' lack of interest in reading is due to a lack of motivation from the environment so that it fosters a sense of laziness, then the problem of gadgets that makes students lazy and doesn't care about studying.

The fact shows that many students get difficulties in learning reading because sometimes they feel bored and the fact they will lazy to understand the subject. Learning difficulties are indicated by the inability/difficulty in language and mathematics ( (Dapa, 2020).

Based on (Nurmalasari \& Haryudin, 2021) stated that the students feeling trouble when they want to interpreting a text, because they have less knowledge of translating every word and then find the main idea of the text they read, they cannot conclude and answering the questions. One thing that makes them bored in learning English is because the teacher focuses on one source. The teacher just follows the source which is provided or designed as teaching material like a book. Usually, in the teaching of the reading, the teacher just gives the textbook which is the students have always seen before. When the students are asked to read, they will feel bored. As a consequence, the student only keeps silent and others are talking. The class becomes noisy. When it happens, the student's motivation is lost. Therefore teachers have to find a solution to solve the problem above. Various materials are expected to help students to enhance their motivation in learning English.

\subsection{Research questions}

The objective of the research is to know the use of the genre-based approach (GBA) in teaching reading comprehension at the eighth-grade students of SMP Negeri 1 Sibulue.

The result of the research hoped that research can be beneficial for students and teachers in improving their English, especially in improving their reading skills.

\subsection{Significance of the study}


Related to previous related research finding, the researcher shows some previous studies that have been done as follow;

Based on (Fanani, 2018), described the application of GBA in teaching writing to university students. Where the study was carried out by observing the teacher in the classroom using the Genre-based approach (GBA). The result showed that he had fully implemented GBA which worked very well with the students at the beginner level. The research shows that the use of the Genre-based approach (GBA) is very useful and effective in improving students' writing skills.

Other research, (Daniarti, Taufiq, and Sunaryo, 2020) found that GBA can be used to build the students' motivation (by using the extrinsic factors of motivation), and it can be used to solve the students' difficulties. Moreover, we hope that other researchers will conduct further exploration of the teaching reading procedure text using GBA

Thus, in another research by (Nagao, 2018), said that the preliminary analysis results indicated that that applying a teaching and learning cycle and a genre-based approach to writing instruction has the potential to enhance EFL students' awareness of generic structure and interpersonal meaning in writing argumentative essays.

Based on the research finding above, the researcher concluded that genre-based approach (GBA) in learning English is very useful because it can improve students' abilities and motivation. Therefore, the researcher focuses on how to improve students' reading comprehension in the Sequence Event or Idea, knowledge on specific information and Following Instruction aspect through the genre-based approach (GBA).

\section{METHOD}

\subsection{Research Design}

The implementation of classroom action research (CAR) starts from the planning stage, activities/actions, observations, and reflections.

According to (Khasinah, 2013), she said that Classroom Action Research (CAR) is a research activity that in the context of classes that is carried out to solve problems learning faced by teachers, improve the quality and learning outcomes, and try new things in learning for the sake of improving the quality and learning outcomes

\subsection{Samples/Participants}

The subjects in this study were eighth-grade students for the 2021-2022 academic years. In this study, the researcher took 28 students as the subject consisting of 17 women and 11 men.

\subsection{Instruments}

There are two instruments used, namely observation and reading test by answering multiple choice questions based on the reading text.

\subsection{Data analysis}

Calculating the percentage of the students' activity in learning process using formula:

$$
\mathrm{P}=\frac{F}{N x 4} \times 100 \%
$$

Note:

$\begin{array}{ll}\mathrm{P} & \text { : Percentage } \\ \mathrm{F} & \text { : Frequency }\end{array}$ 


\section{FINDINGS AND DISCUSSION}

\subsection{Findings}

The application of the genre-based approach (GBA) in improving the students' knowledge on specific information means here particular information or detail which the needs from a text. The indicator had a total score and it was divided by the sum of students so it resulted as a means score in D-Test, cycle I, and cycle II. So, the improvement of the students' knowledge of specific information in reading can be shown clearly in the following explanation;

Table 1: The Students' Improvement knowledge on specific information in reading

\begin{tabular}{cccccc}
\hline \multirow{2}{*}{ Indicators } & \multicolumn{2}{c}{ Specific Information } & \multicolumn{2}{c}{ Improvement } \\
\cline { 2 - 5 } & D- Test & Cycle I & Cycle II & D-test to CI & CI to CII \\
\hline Mean score & 52.84 & 66.2 & 80 & 25.28 & 20.84 \\
\hline
\end{tabular}

The table above indicated that there was improvement of the students' knowledge on specific information from D-Test to cycle I and cycle II, where in D-Test the students' mean score achievement on specific information in reading was 52.84 but after evaluation in cycle I the students' knowledge on specific information became 66.2, so the improvement of students' knowledge on specific information achievement from D-Test to cycle I was 25.28 There was also a significant improvement of students' knowledge on specific information from cycle I to cycle II where the students' knowledge on specific information in cycle I was 66.2 and in cycle II was 80 , so the improvement of students' knowledge on specific information achievement from cycle I to cycle II was 20.84

Table 2: The Improvement of the Students' knowledge on Sequence Event or Idea in Reading

\begin{tabular}{cccccc}
\hline \multirow{2}{*}{ Indicators } & \multicolumn{3}{c}{ Sequence Event or Idea } & \multicolumn{2}{c}{ Improvement } \\
\cline { 2 - 6 } & D- Test & Cycle I & Cycle II & $\begin{array}{c}\text { D-test to } \\
\text { CI }\end{array}$ & CI to CII \\
\hline Mean score & 49.2 & 61 & 74 & 23.98 & 21.31 \\
\hline
\end{tabular}

Based the table showed that there was improvement of the students' knowledge on Sequence Event or Idea from D-Test to cycle I and cycle II, where in D-Test the students' mean score achievement on Sequence Event and Idea was 49.2 but after evaluation in cycle I the students' knowledge on Sequence Event or Idea became 61, so the improvement of students' knowledge on Sequence Event or Idea achievement from D-Test to cycle I was 23.98 There was also a significant improvement of students' knowledge on Sequence Event or Idea from cycle I to cycle II where the students' Sequence Event or Idea in cycle I was 61 and in cycle II was 74, therefore the students 'improvement on Sequence Event or Idea achievement from cycle I to cycle II was 21.31 
Table 3: The Improvement of the Students' knowledge on Following Instruction in reading

\begin{tabular}{cccccc}
\hline \multirow{2}{*}{ Indicators } & \multicolumn{3}{c}{ Following Instruction } & \multicolumn{2}{c}{ Improvement } \\
\cline { 2 - 6 } & D- Test & Cycle I & $\begin{array}{c}\text { Cycle } \\
\text { II }\end{array}$ & D-test to CI & CI to CII \\
\hline Mean score & 47.49 & 58.2 & 73 & 22.55 & 25.42
\end{tabular}

The table above indicated that there was an improvement of the students' knowledge on Following Instruction from D-Test to cycle I and cycle II, where in D-Test the students' mean score achievement on Following Instruction in reading was 49.49 but after evaluation in cycle I the students' knowledge on Following Instruction became 66.2, so the improvement of students' knowledge on following instruction achievement from D-Test to cycle I was 22.55 There was also a significant improvement of students' knowledge on following instruction from cycle I to cycle II where the students' knowledge on following the instruction in cycle I was 58.2 and in cycle II was 73 , so the improvement of students' knowledge on following instruction achievement from cycle I to cycle I was 25.42

Table 4: The Students 'Improvement in Reading comprehension

\begin{tabular}{|c|c|c|c|c|c|c|c|c|c|c|c|}
\hline & \multicolumn{9}{|c|}{ Reading Comprehension } & \multicolumn{2}{|c|}{ Improvement } \\
\hline & \multicolumn{3}{|c|}{ D- Test } & \multicolumn{3}{|c|}{ Cycle I } & \multicolumn{3}{|c|}{ Cycle II } & \multirow{2}{*}{$\begin{array}{c}\text { D-T to } \\
\text { CI }\end{array}$} & \multirow{2}{*}{$\begin{array}{c}\text { CI } \\
\text { to } \\
\text { CII }\end{array}$} \\
\hline & SI & SEI & FI & SI & SEI & FI & SI & SEI & FI & & \\
\hline Mean & 52.84 & 49.24 & 47.9 & 66.2 & 61 & 58.2 & 80 & 74.4 & 73 & & \\
\hline \multirow[t]{2}{*}{ Score } & & & 2 & & & & & & & & \\
\hline & & 50.00 & & & 61.80 & & & 75.80 & & 23.6 & 22.7 \\
\hline
\end{tabular}

The table above indicated that there was an improvement of the students' reading Comprehension from D-Test to cycle I and cycle II, where in D-Test the students' mean score achievement in reading comprehension was 50.00 , but after evaluation in cycle I, the students' reading comprehension was 61.80 . So the improvement of students' reading comprehension achievement from D-Test to cycle I was 23.6. There was also a significant improvement in students reading comprehension from cycle I to cycle II where the students' reading comprehension in cycle I was 61.80 and in cycle II was 75.80. So the improvement of students' reading comprehension achievement from cycle I to cycle II was 22.7

The table above showed that there was a significant improvement in students' reading comprehension after taking an action in cycle I and cycle II through the application of Genre Based (GBA) approach. 
Table 5. The observation result of the students' activeness in learning process.

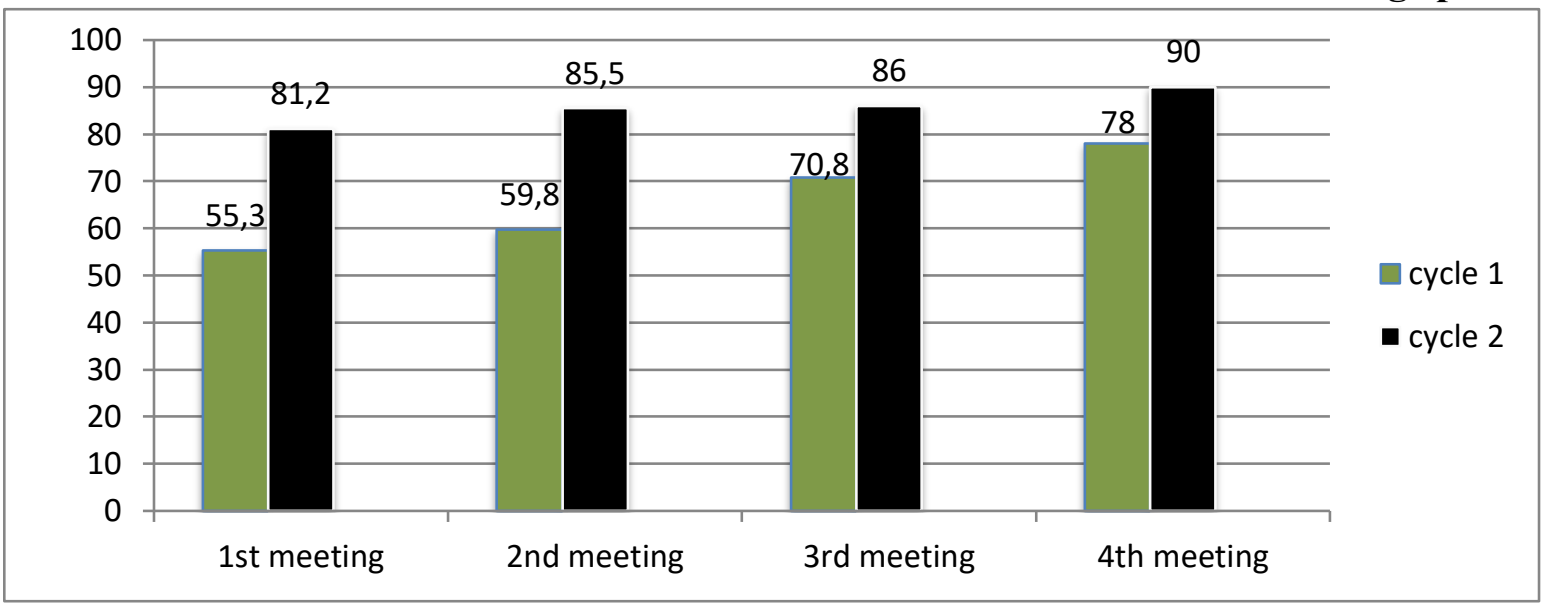

Based on the chart showed that the result of students' activeness in the teaching and learning process was improved through the use of the Genre Based (GBA) approach, where in the first meeting in the cycle one, the students' activeness was $55.3 \%$ improved to $59.8 \%$ in the second meeting, then in the third meeting was $70.8 \%$ improved to $78 \%$ in the fourth meeting, there fore the mean score of the students' activeness in learning reading process in the cycle I was $65.97 \%$.

As for the second cycle, the increase in student activity increased well. Where in the second cycle, student activity reached $81.2 \%$ improved to $85.5 \%$ in the second meeting. In the third meeting become $86 \%$ then improved to $90 \%$ in the fourth meeting. Therefore, the activeness of students in the second cycle becomes $85.72 \%$.

\subsection{Discussion}

In this part, discussion deals with the interpretation of findings derived from the result of findings about the observation result of the students' reading comprehension; they are knowledge specific information, sequence event or idea and following instruction and the observation score and result of the students' activeness in learning process by using Genre Based (GBA) approach.

Before taking a classroom action research through Genre Based (GBA) approach, researcher conduct diagnostic tests to measure and test students' reading skills. After giving D-Test, the researcher found that the student's knowledge of specific information in reading at the eighth grade of SMP Negeri 1 Sibulue was poor, so it must be improved. The D-Test's score was that 3 students (12\%) got fairly good, 9 students (36\%) got fair, 11 students (44\%) got poor and 2 students $(8 \%)$ got very poor classification, D-Test the students' knowledge on sequence event or idea, students' achievement was 4 students (16\%) got fair, 19 students (76\%) poor, 2 students (8\%) got very poor classification, and D-Test the students' knowledge on the following instruction, students' achievement was 3 students (12\%) got fair, 20 students (40\%) poor, 2 students $(8 \%)$ got very poor classification.

To improve the students reading comprehension, the researcher used Genre Based (GBA) approach and then prepared to do cycle I that consisted of 4 phases namely: planning, action, observation, and reflecting. In cycle 1 , the researcher found that the students are still difficult and confused to determine and find the important point in a text that we usually called comprehension. Besides that the student's pronunciation and stress in reading aloud are very low. 
The difficulty of the students in reading had been analyzed, so the researcher had to think of the good solution to the problem. The researcher decided to do cycle II by revising the lesson plan. In cycle II, the researcher got a good response from the students. Students are active and confident to learn in English. They can enjoy the learning process, and their score was improved in cycle II.

In cycle $I$, the students' knowledge on specific information in reading was there were 5 students (20\%) got good, 14 students (56\%) got fairly good, 6 students (24\%) got fair, the students' knowledge on sequence event or idea in reading was 9 students $(36 \%)$ got fairly good, 14 students (56\%) got fair, and 2 students (8\%), and the students' knowledge on following in reading was 3 students (12\%) got fairly, 19 students (76\%), and 3 students (12\%). in cycle II, the student's knowledge of specific information was 6 students $(24 \%)$ got very good, 18 students (72\%) got good, and 1 student (4\%) got fairly good. the students' knowledge of sequence events or idea was 17 students (68\%) got good and 8 students (32\%) got fairly good, and the students' knowledge on the following instruction was 6 students (24\%) got very good, 14 students (56\%) got good, and 11 students (44\%) got fairly good.

The mean score of the students' reading comprehension in cycle I was 61.80 and classified as fairly good. While the mean score in cycle II was 75.80 classified as good the students' improvement was 22.7. It means that the students' reading comprehension improved significantly through Genre Based (GBA) approach.

The result of students' activeness in the learning process developed significantly through the implementation of the Genre Based (GBA) approach in improving the students' reading comprehension. It was proved by the improvement of the mean score of the students' activeness in cycle I namely $65.97 \%$ became $85.72 \%$ in cycle II. It also means that there is an improvement of the students' activeness in learning reading comprehension through Genre Based (GBA) approach.

The Results showed that Genre Based (GBA) approach was effective in developing the students' reading comprehension in Junior high school, which is confirmed the findings by (Fanani, 2018);(Daniarti, Taufiq, and Sunaryo, 2020); and (Nagao, 2018) who was the same for this research.

\section{CONCLUSIONS}

\subsection{Conclusion}

Based on the results of research on teaching reading comprehension through genre-based approach (GBA) at Junior high school, then the researcher draws a conclusion as follows; There was different score between cycle I and cycle II in the teaching and learning process reading comprehension through Genre Based approach (GBA). The researcher concluded that teaching reading comprehension through Genre Based approach (GBA) was effective approach to develop the students' reading skills.

The observation result of students' activeness in learning process developed significantly through the application of Genre Based approach (GBA) in improving the students' reading comprehension. It was proved by the improvement of the mean score of the students' activeness in cycle I namely $65.97 \%$ became $85.72 \%$ in cycle II. It also means that there was improvement 
of the students' activeness in learning reading comprehension through Genre Based approach (GBA).

\subsection{Suggestions}

In this term, the researcher pointed some suggestions for the English teacher and also all of the students. Generally, teacher should create various activities to create teaching and learning process and engage the students lively and interesting in the classroom. English teacher should to apply Genre Based approach (GBA) as one of ways in improving the students' reading comprehension, and the teacher should apply various kinds of suitable technique in teaching and learning reading comprehension

\section{REFERENCES}

C. Nuttal, Teaching Reading Skills in a Foreign Language. London: Heinemann Educational Books Ltd, 1982.

Calet, N., Pérez-Morenilla, M. C., \& De los Santos-Roig, M. (2019). Overcoming reading comprehension difficulties through a prosodic reading intervention: A single-case study. Child Language Teaching and Therapy, 35(1). https://doi.org/10.1177/0265659019826252

Daniarti, Y., Taufiq, R., \& Sunaryo, B. (2020). The Implementation of Teaching Reading Through Genre Based Approach for University Students. Journal of Physics: Conference Series, 1477(4). https://doi.org/10.1088/1742-6596/1477/4/042064

Dapa, A. N. (2020). Differentiated Learning Model For Student with Reading Difficulties. JTP Jurnal Teknologi Pendidikan, 22(2). https://doi.org/10.21009/jtp.v22i2.15814

Fanani, A. (2018). THE IMPLEMENTATION OF GENRE-BASED APPROACH IN TEACHING WRITING BY A UNIVERSITY TEACHER IN JOMBANG. JURNAL SMART, 4(2). https://doi.org/10.26638/js.700.203x

Floris, F. D., \& Divina, M. (2015). A STUDY ON THE READING SKILLS OF EFL UNIVERSITY STUDENTS. TEFLIN Journal - A Publication on the Teaching and Learning of English, 20(1). https://doi.org/10.15639/teflinjournal.v20i1/37-47

Khasinah, S. (2013). Classroom Action Research. Jurnal Pionir, Volume 1, Nomor 1, 1(2).

Nagao, A. (2018). A Genre-Based Approach to Writing Instruction in EFL Classroom Contexts. English Language Teaching, 11(5). https://doi.org/10.5539/elt.v11n5p130

Nurmalasari, N., \& Haryudin, A. (2021). THE STUDENTS' DIFFICULTIES IN LEARNING READING. PROJECT (Professional Journal of English Education), 4(1). https://doi.org/10.22460/project.v4i1.p29-34

Sari, M. H., Susetyo, Noermanzah, Wardhana, D. E. C., \& Kusumaningsih, D. (2020). Understanding the level of students' reading comprehension ability. Universal Journal of Educational Research, 8(5). https://doi.org/10.13189/ujer.2020.080521

Satriani, E. (2018). Reading Comprehension Difficulties Encountered by English Students of Islamic University of Riau. J-SHMIC: Journal of English for Academic, 5(2). https://doi.org/10.25299/jshmic.2018.vol5(2).1885

Sudjana. (2005). sudjana. In Metoda statistika.

Suyana, N. (2019). MENINGKATKAN KEMAMPUAN MEMBACA PEMAHAMAN MELALUI METODE PREVIEW, QUESTION, READ, STATE, DAN TEST (PQRST). JIPIS, 28(2). https://doi.org/10.33592/jipis.v28i2.308 